\title{
ANALISIS PERUBAHAN STRUKTUR KRISTAL DAN DISTRIBUSI KATION COBALT FERRITE AKIBAT SUBTITUSI ZINC
}

\author{
HERI KISWANTO * \\ Prodi Fisika, Institut Teknologi dan Sains Nahdlatul Ulama Pekalongan \\ Jl. Karangdowo no 9 Kedungwuni Pekalongan, Jawa Tengah 51173 \\ *email : herikis@itsnupekalongan.ac.id
}

\begin{abstract}
Abstrak. Sampel cobalt zinc ferrite telah berhasil disintesis menggunakan metode kopresipitasi dengan memvariasikan konsentrasi zinc yaitu 0\%, 25\%, 50\%, 75\% dan $90 \%$. Struktur krsital, gugus fungsi dan morfologi dikarakterisasi secara detail dengan $X$ ray Diffractometer (XRD), Transmission Electron Microscope (TEM), and Fourier Transform Infrared (FTIR). Distribusi kation dianalisis secara teori dan didukung dengan hasil penelitian sebelumnya. Ukuran kristalit diestimasi dengan metode Scherrer yang ditemukan menurun dari 10,8 nm - 9,5 nm, sedangkan parameter kisi ditemukan meningkat dari 8,19-8,26 ̊̊ seiring dengan meningkatnya konsentrasi zinc. Distribusi kation dipengaruhi oleh subtitusi zinc akibat preferensi kation menempati sub ruang (kisi) tertentu. Karakterisasi TEM menunjukkan ukuran butir pada sampel beragam dan mengalami aglomerasi.
\end{abstract}

Kata kunci: cobalt zinc ferit, subtitusi zinc, struktur kristal, distribusi kation

\begin{abstract}
Cobalt zinc ferrite nanoparticle samples were successfully synthesized via coprecipitation method by varying zinc concentration i.e. $0 \%, 25 \%, 50 \%, 75 \%$ and $90 \%$. The crystal structure, functional group and morphology were characterized in detail by X-ray Diffractometer (XRD), Transmission Electron Microscope (TEM), and FourierTransform Infrared (FTIR). The cation distribution were analyzed by the theory dan supported by the previous researches. The crystallites size was estimated Scherrer method was found to decrease from $10.8 \mathrm{~nm}-9.5 \mathrm{~nm}$, while with the lattice parameter was found to increase from 8.19 to $8.26 \AA$ by increasing zinc concentrations. The cation distribution was influenced by zinc subtitution due to cation's preferences to occupy the specific site. TEM characterization showed the various grain size in the samples and agglomeration had occurred.
\end{abstract}

Keywords: cobalt zinc ferrite, zinc subtitution,, crystal structure, cation distribution

\section{Pendahuluan}

Dewasa ini perkembangan riset nanomaterial semakin banyak diminati. Nanomaterial berkembang karena dorongan kebutuhan akan material dengan karakteristik tertentu yang tidak terdapat di alam. Alih-alih mencari material dengan karakteristik yang diinginkan, para peneliti lebih cenderung melakukan proses rekayasa pada material berskala nano untuk mendapatkan karakteristik tersebut, dimana fenomena-fenomena unik yang muncul dapat digunakan untuk aplikasiaplikasi baru [1]. Beberapa tahun terakhir sebagian besar riset nanomaterial difokuskan pada desain struktur materialnya, misalnya pada nanopartikel magnetik.

Nanopartikel ferit merupakan salah satu jenis nanopartikel magnetik yang banyak dikaji karena banyaknya potensi aplikasi yang dihasilkan [2]. Dalam skala industri, 
ferit banyak digunakan dalam produksi beragam perangkat elektronik, sensor, dan lain-lain. Dalam skala penelitian, tujuan utamanya adalah membuat material ferit yang memiliki karakteristik khusus sesuai aplikasi yang diinginkan. Oleh karena itu pengolahan nanopartikel ferit ini menjadi penting dan menarik untuk dikaji. Hal ini tidak lepas karena keunggulan sifat-sifat fisika maupun kimia material ferit dibandingkan kelompok material lainnya. Sifat unggul tersebut bergantung pada berbagai faktor, diantaranya jenis doping, derajat kristalinitas, struktur kristal, distribusi kation serta morfologi partikel [3-5]. Oleh akrena itu penelitian terkait material ferit ini menjadi penting dan menarik untuk dikaji.

Salah satu material ferit yang banyak dikembangkan adalah cobalt zinc ferrite, yang banyak diaplikasikan pada perangkat frekuensi tinggi [6]. Penelitian sebelumnya telah mengungkap bahwa substitusi zinc pada cobalt ferrite secara signifikan mempengaruhi struktur kristalnya. Huo dkk. menyatakan bahwa subtitusi zinc pada cobalt ferrite meningkatkan nilai parameter kisi [7]. Ali dkk. juga mengkonfirmasi bahwa penambahan zinc pada cobalt ferrite secara signifikan meningkatkan nilai parameter kisi dan densitas [8]. Hassadee juga melakukan penelitian terkait cobalt zinc ferrite dan menyatakan bahwa parameter kisi meningkat seiring dengan meningkatnya konsentrasi zinc [8].

Beberapa penelitian terkait subtitusi zinc pada cobalt ferrite telah dilakukan dengan metode dan konsentrasi yang berbeda-beda, namun sejauh ini penelitian sebelumnya hanya meneliti pengaruh zinc pada konsentrasi rendah. Oleh karena itu, perlu dilakukan penelitian lebih lanjut terkait pengaruh konsentrasi zinc dengan konsentrasi yang lebih bervariatif. Penelitian ini difokuskan untuk mempelajari perubahan struktur kristal dan distribusi kation pada cobalt zinc ferrite.

\section{Metode Penelitian}

Sampel cobalt zinc ferrite disintesis dengan metode kopresipitasi pada suhu rendah. Bahan yang digunakan untuk mensintesis nanopartikel, yaitu: $\mathrm{Fe}\left(\mathrm{NO}_{3}\right)_{3} .9 \mathrm{H}_{2} \mathrm{O}$, $\mathrm{Co}(\mathrm{NO})_{3} .6 \mathrm{H}_{2} \mathrm{O}, \mathrm{ZnSO}_{4} .6 \mathrm{H}_{2} \mathrm{O}$ dan larutan $\mathrm{NaOH}$ yang berfungsi sebagai agen pengendap. Adapun konsentrasi $\mathrm{Zn}$ divariasikan dari 0\%, 25\%, 50\%, 75\% dan 90\%. Proses kopresipitasi diawali dengan membuat larutan garam logam $\mathrm{Fe}\left(\mathrm{NO}_{3}\right)_{3} \cdot 9 \mathrm{H}_{2} \mathrm{O}$, larutan garam logam campuran $\mathrm{Co}\left(\mathrm{NO}_{3}\right)_{3} .6 \mathrm{H}_{2} \mathrm{O}$ dan $\mathrm{ZnSO}_{4} \cdot 6 \mathrm{H}_{2} \mathrm{O}$ pada suhu ruang. Kemudian larutan $\mathrm{NaOH}$ diteteskan pada larutan logam campuran diaduk pada suhu $70^{\circ} \mathrm{C}$ dengan laju pengadukan $1000 \mathrm{rpm}$. Setelah itu presipitat diendapkan hingga mencapai suhu ruang. Proses drying dilakukan dengan furnace pada suhu $120^{\circ} \mathrm{C}$ selama 2 jam untuk memperoleh sampel powder. Sampel kemudian dikarakterisasi dengan $X$-Ray Diffractometer dengan panjang gelombang sinar-X $(\lambda \mathrm{Cu} \mathrm{K \alpha}) 1,5406 \AA$. Analisis gugus fungsi dilakukan dengan FTIR Spectroscopy, sedangkan pengamatan morfologi dilakukan dengan Transmission Electron Microscopy.

\section{Hasil dan Pembahasan}

\subsection{Struktur Kristal Cobalt Zinc Ferrite}

Kajian struktur kristal cobalt zinc ferrite didasarkan pada hasil karakterisasi XRD yang disajikan pada Gambar 1.

Pada Gambar 1(a) terdapat lima puncak difraksi (peak) yang diidentifikasi sebagai bidang (220), (311), (400), (422), (511), dan (440). Peak dengan intensitas tertinggi 
yaitu bidang (311) dipilih untuk mengidentifikasi struktur kristal pada sampel. Dapat diamati bahwa dengan meningkatnya konsentrasi zinc menyebabkan intensitas peak menurun serta mengalami pelebaran (peak broadening) yang mengindikasikan menurunnya derajat kristalinitas (crystallinity). Selain itu, sudut puncak difraksi bidang kristal (311) mengalami pergeseran seiring dengan meningkatnya konsentrasi zinc seperti ditunjukkan pada Gambar 1 (b). Penurunan intensistas maupun pergeseran peak ini diduga terjadi akibat adanya strain. Strain merupakan indikasi adanya defek atau cacat kristal yang terjadi akibat pola distribusi ion nanopartikel yang tidak semestinya akibat adanya vacancy, dislokasi kisi, stacking faults, serta triple junction pada nanopartikel [9].

(a)

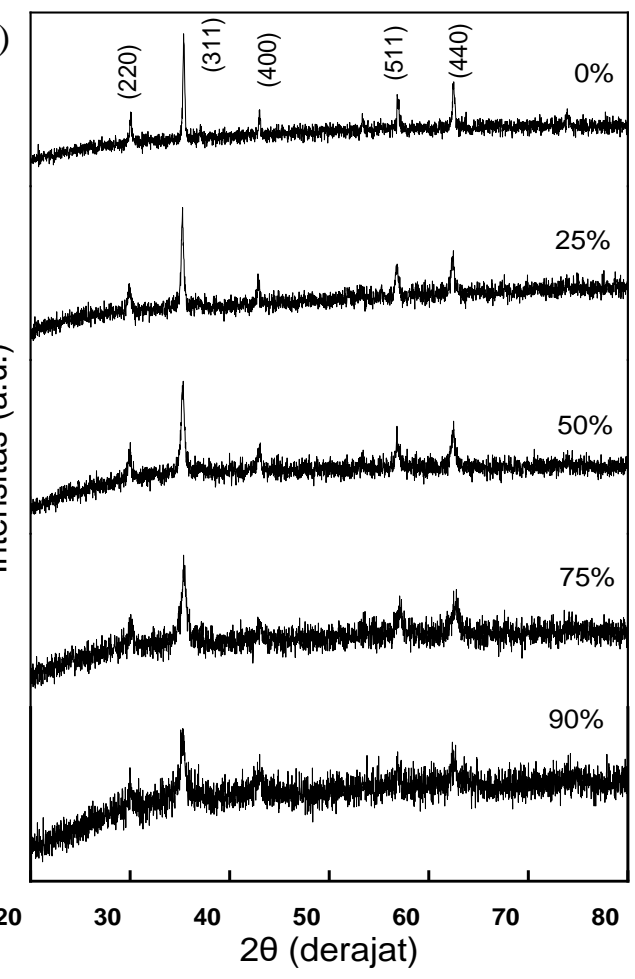

(b)

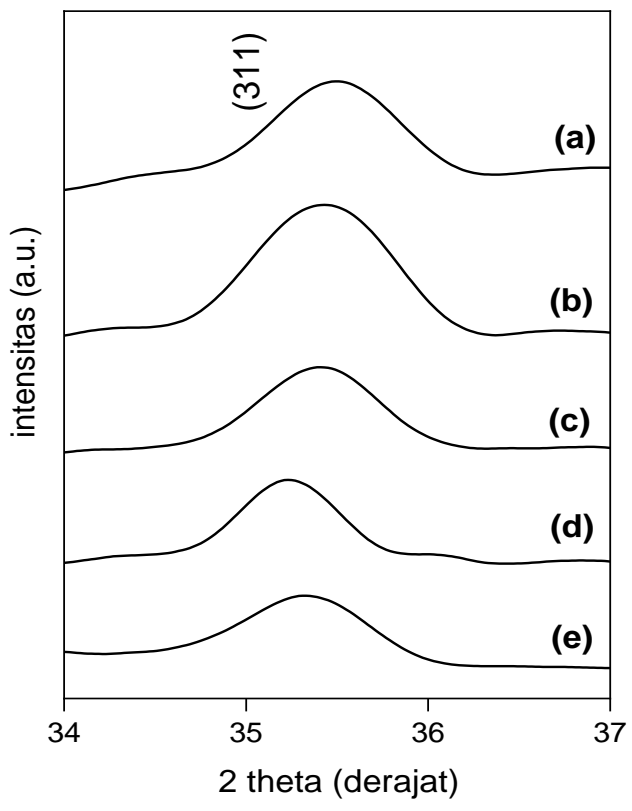

Gambar 1. (a) Pola XRD cobalt zinc feritte variasi konsentrasi zinc; (b) Pergeseran sudut puncak difraksi cobalt zinc feritte

Konsentrasi zinc juga berpengaruh pada ukuran kristalit dan parameter kisi. Pengaruh konsentrasi zinc terhadap ukuran kristalit dan parameter kisi ditunjukkan pada Gambar 2.

Ukuran kristalit cobalt zinc ferrite diestimasi dengan menggunakan metode Scherrer:

$$
t=\frac{0.9 \lambda}{\beta \cos \theta}
$$

dimana $t$ menyatakan ukuran kristalit $(\mathrm{nm}), k$ adalah konstanta $\operatorname{Scherrer}(0,9)$ dan $\beta$ menyatakan FWHM (full width at half maximum) dari puncak difraksi bidang (311). Sedangkan parameter kisi dihitung dengan persamaan berikut, 


$$
a=d \sqrt{h^{2}+k^{2}+l^{2}}
$$

dimana $a$ adalah parameter kisi, $\lambda$ adalah panjang gelombang, $\theta$ adalah sudut $B r a g g$, $\mathrm{d}$ adalah jarak antar bidang dan (h k l) adalah indeks Miller..

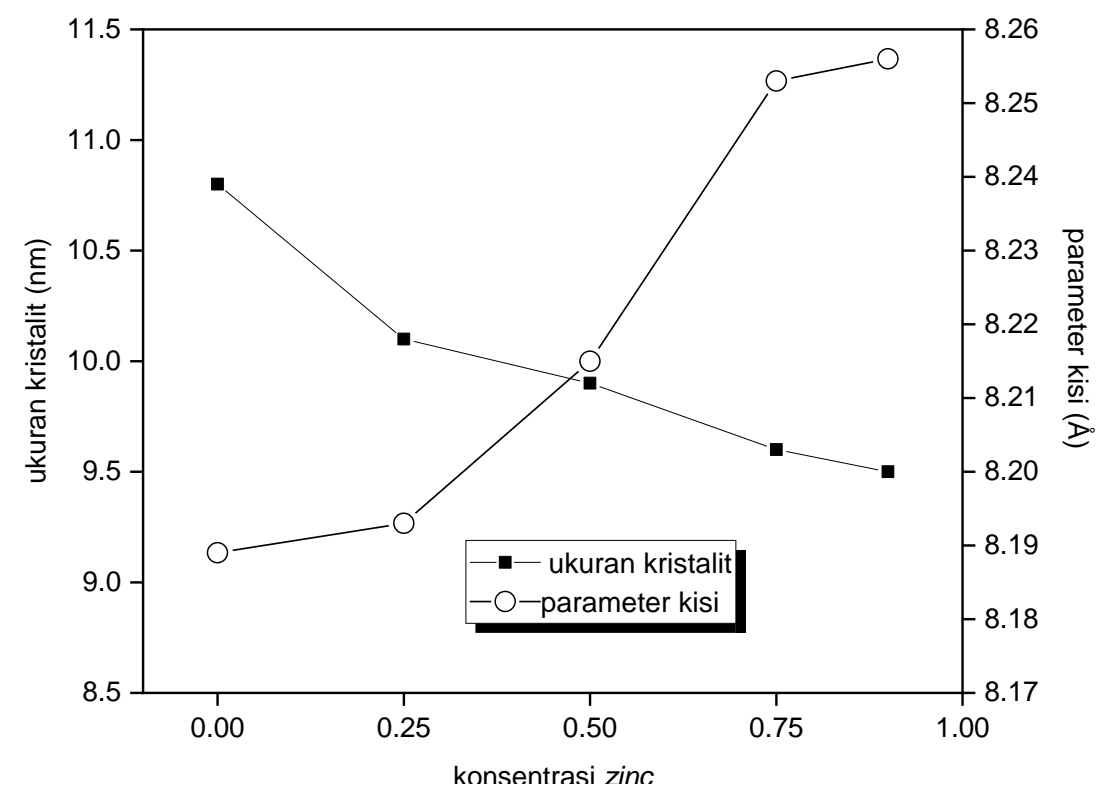

Gambar 2. Pengaruh konsentrasi Zinc terhadap ukuran kristalit dan parameter kisi

Pada Gambar 2, dapat diamati bahwa ukuran kristalit cenderung menurun dari seiring dengan meningkatnya konsentrasi zinc. Faktor yang diduga mempengaruhi ukuran kristalit pada cobalt zinc ferrite adalah strain [7]. Kecenderungan kation $\mathrm{Zn}^{2+}(0,60 \AA)$ untuk menempati kisi tetrahedal (A), memaksa Fe $\mathrm{Fe}^{3+}(0,65 \AA)$ untuk berpindah ke kisi Octahedral (B) sehingga membentuk vacancy karena adanya perbedaan jari-jari ionic [8]. Vacancy inilah yang diduga menyebabkan munculnya strain. Menurut Ali dkk., menurunnya ukuran kristalit adalah karena energi ikat $\mathrm{Zn}^{2+}-\mathrm{O}^{2-}(159 \mathrm{~kJ} . \mathrm{mol})$ lebih rendah daripada energi ikat $\mathrm{Co}^{2+}-\mathrm{O}^{2-}(384 \mathrm{~kJ} / \mathrm{mol})$ [9]. Energi ikat yang rendah menyebabkan atom-atom penyusun tidak dapat berikatan dengan kuat sehingga ukuran kristalit yang terbentuk relatif kecil. Sedangkan parameter kisi cenderung meningkat dari 8,19 hingga 8,26 ̊. Hal ini dikarenakan subtitusi $\mathrm{Zn}^{2+}(0.60 \AA)$ yang memilikki jari-jari kation lebih besar daripada $\mathrm{Co}^{2+}(0.58 \AA)$ sehingga memicu terjadinya ekspansi dalam unit sel [10].

\subsection{Distribusi Kation Cobalt Zinc Ferrite}

Proses pembentukan dan pertumbuhan kristalit nanopartikel sangat dipengaruhi oleh kecenderungan suatu ion menempati sub ruang (kisi) tertentu seperti yang ditunjukkan pada Gambar 3.

Kation $\mathrm{Zn}^{2+}$ cenderung menempati kisi tetrahedral (A) karena bentuk bulk-nya memiliki struktur normal spinel, dimana kation $\mathrm{Zn}^{2+}$ cenderung menempati kisi tetrahedral. Sedangkan kation $\mathrm{Co}^{2+}$ yang memiliki struktur invers spinel, dimana kation $\mathrm{Co}^{2+}$ terdistribusi pada kisi tetrahedral maupun kisi Oktahedral (B) [11]. Sebagai justifikasi, hasil penelitian Kumar dkk. terkait distribusi kation cobalt zinc 
ferrite berdasarkan hasil karakterisasi spektroskopi Mössbauer seperti yang disajikan pada Tabel 1 .

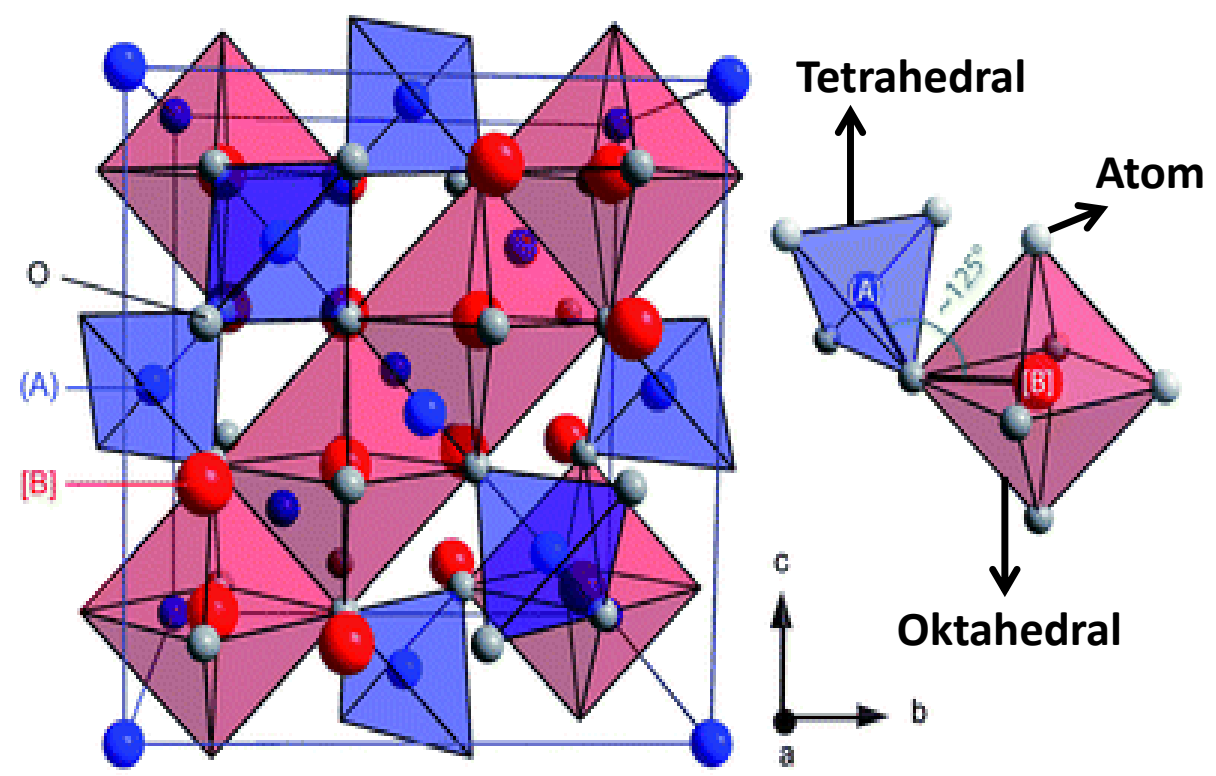

Gambar 3. Ilustrasi posisi kation pada site Tetrahedral dan Oktahedral (Panda, 2015)

Tabel 1. Distribusi kation nanopartikel Cobalt Zinc Ferrite

\begin{tabular}{ccc}
\hline Sampel & Site A [Tetrahedral $]$ & Site $\mathbf{B}$ (Oktahedral) \\
\hline $\mathbf{C o Z n F e}_{2} \mathrm{O}_{4}$ & {$\left[\mathrm{Co}_{0,11} \mathrm{Fe}_{1,11}\right]$} & $\left(\mathrm{Co}_{0,89} \mathrm{Fe}_{0,89}\right)$ \\
$\mathrm{CoZn}_{0,1} \mathrm{Fe}_{2} \mathbf{O}_{4}$ & {$\left[\mathrm{Zn}_{0,085} \mathrm{Co}_{0,089} \mathrm{Fe}_{0,896}\right]$} & $\left(\mathrm{Co}_{0,991} \mathrm{Fe}_{1,004} \mathrm{Zn}_{0,015}\right)$ \\
$\mathbf{C o Z n}_{0,2} \mathrm{Fe}_{2} \mathbf{O}_{4}$ & {$\left[\mathrm{Zn}_{0,17} \mathrm{Co}_{0,152} \mathrm{Fe}_{0,98}\right]$} & $\left(\mathrm{Co}_{0,848} \mathrm{Fe}_{0,96} \mathrm{Zn}_{0,03}\right)$ \\
\hline
\end{tabular}

Secara teoretik distribusi ion-ion $\mathrm{Co}, \mathrm{Zn}$ dan Fe pada nanopartikel dapat dituliskan pada persamaan berikut [12].

$$
\left[\mathrm{Zn}_{x}^{2+} \mathrm{Co}_{1-x}^{2+} \mathrm{Fe}_{1-y}^{3+}\right]_{A}\left[\mathrm{Co}_{x}^{2+} \mathrm{Fe}_{1-y}^{+}\right]_{B}(\mathrm{O})^{2-}
$$

Selama sintesis, kation $\mathrm{Zn}^{2+}$ akan lebih cenderung menempati kisi tetrahedral (A), sedangkan kation $\mathrm{Co}^{2+}$ cenderung menempati kisi octahedral (B) karena memiliki afinitas yang lebih rendah. Meningkatnya kation $\mathrm{Zn}^{2+}$ yang menempati kisi $\mathrm{A}$, memaksa kation $\mathrm{Fe}^{3+}$ untuk pindah ke kisi B [11]. Hal ini tentu akan mempengaruhi distibusi ion yang menempati kedua kisi, yang berimplikasi pada ukuran partikel [13]. Distribusi kation ini sekaligus menjelaskan bahwa dengan bertambahnya konsentrasi zinc menyebabkan parameter kisi meningkat akibat adanya ekspansi volume kristal yang dipicu subtitusi kation $\mathrm{Zn}^{2+}$ pada kisi tetrahedral.

\subsection{Gugus Fungsi Cobalt Zinc Ferrite}

Gugus fungsi nanopartikel cobalt zinc ferrite dikarakterisasi dengan FTIR spectroscopy. Spektra FTIR sampel cobalt zinc ferrite disajikan pada Gambar 4. 
Dalam spektra tersebut terindentifikasi beberapa gugus fungsi. Secara umum, variasi konsentrasi $\mathrm{Zn}$ tidak berdampak signifikan terhadap profil spektra FTIR nanopartikel. Gugus fungsi M - O pada daerah oktahedral dan tetrahedral, mengkonfirmasi bahwa sampel cobalt zinc ferrite terbukti memiliki struktur spinel. Berdasarkan Gambar 5, pada bilangan gelombang $432,1-433,1 \mathrm{~cm}^{-1}$ terjadi vibrasi stretching gugus $\mathrm{M}_{\mathrm{okt}}-\mathrm{O}$. Gugus yang dimaksud adalah $\mathrm{Co}-\mathrm{O}$ dan $\mathrm{Fe}-\mathrm{O}$ yang menempati kisi octahedral. Sedangkan pada interval bilangan gelombang $586,3 \mathrm{~cm}^{-}$ ${ }^{1}$ terjadi vibrasi stretching gugus $\mathrm{M}_{\mathrm{tet}}-\mathrm{O}$, yang diduga adalah gugus $\mathrm{Zn}-\mathrm{O}$ yang menempati kisi tetrahedral.

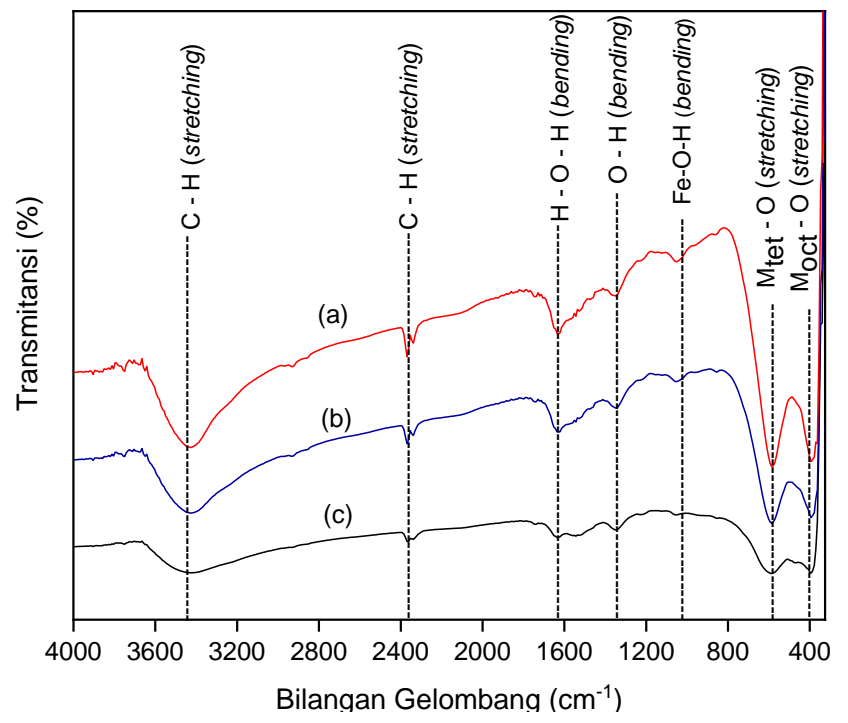

Gambar 4. Gugus Fungsi cobalt zinc ferrite dengan konsentrasi zinc (a) $25 \%$ (b) $50 \%$ (c) $75 \%$

\subsection{Pengamatan Morfologi Cobalt Zinc Ferrite}

Pengamatan morfologi didasarkan pada hasil karakterisasi TEM yang disajikan pada Gambar 5.

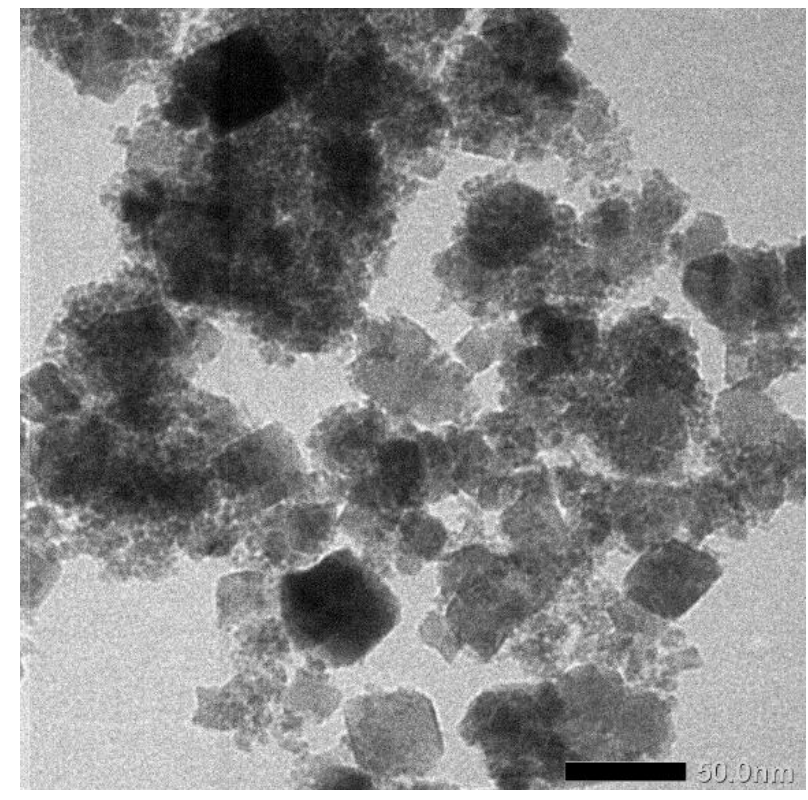

Gambar 5. Hasil Karakterisasi TEM cobalt zinc ferrite 
Berdasarkan gambar 5, tampak sampel mengalami aglomerasi. Aglomerasi diduga terjadi karena ukuran nanopartikel yang sangat kecil sehingga memiliki luas permukaan spesifik dan tegangan permukaan antar-muka yang besar. Hal ini menyebabkan energi pada permukaan nanopartikel tinggi yang membuat nanopartikel tidak stabil [9], sehingga partikel satu dengan partikel yang lainnya akan berikatan satu dengan yang lainnya untuk membuat stabil kembali. Ikatan antar partikel tersebut yang menyebabkan terjadinya aglomerasi.

Hasil karakterisasi TEM juga menyajikan citra SAED (Selected Area Electron Diffraction) seperti ditunjukkan pada Gambar 6.

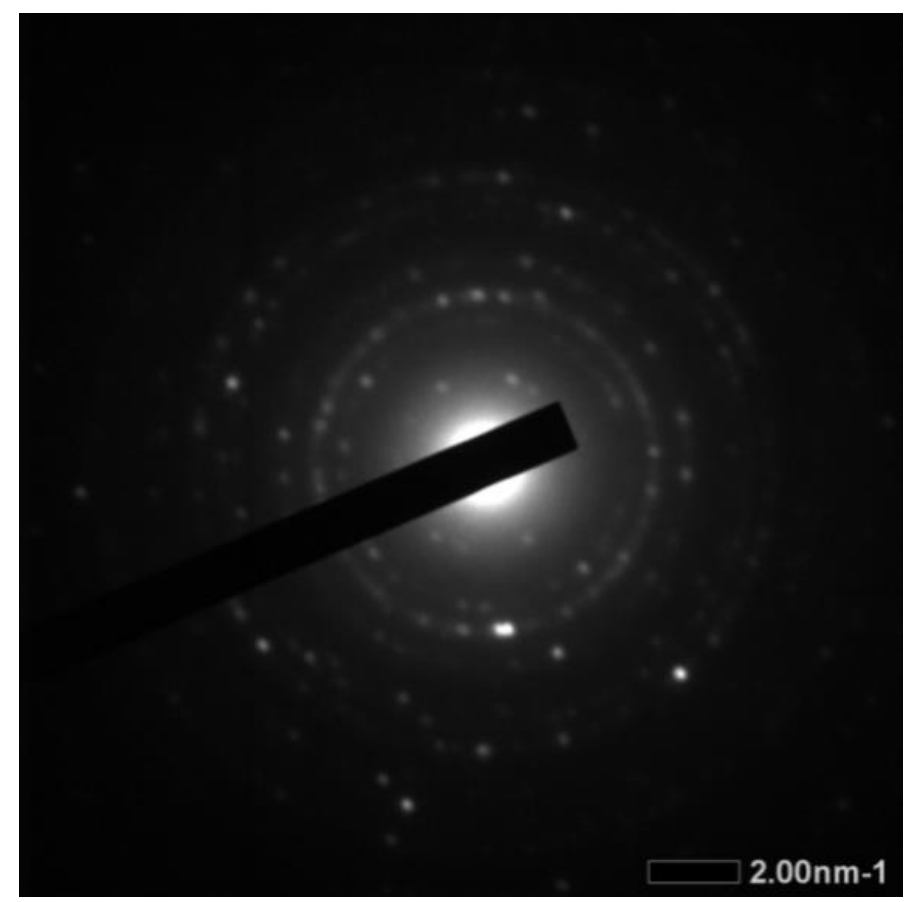

Gambar 6. Citra SAED sampel cobalt zinc ferrite

Berdasarkan Gambar 6, terdapat cincin-cincin difraksi berupa titik-titik (spot) yang membentuk beberapa lingkaran dengan jari-jari tertentu. Pola cincin difraksi yang terbentuk menandakan bahwa sampel berupa material polikiristalin dimana jari-jari tertentu tersebut merepresentasikan bidang-bidang kristal sesuai hasil pola XRD. Intensitas cincin difraksi yang terbentuk tidak kontinyu menandakan bahwa sampel nanopartikel memiliki derajat kristalinitas yang rendah.

\section{Kesimpulan}

Subtitusi zinc terbukti mempengaruhi struktur kristal cobalt ferrite. Hal ini ditandai dengan perubahan parameter struktur kristal seperti menurunnya derajat kristalinitas dan ukuran kristalit, serta meningkatnya parameter kisi seiring dengan meningkatnya konsentrasi zinc. Secara umum, konsentrasi zinc tidak berdampak signifikan terhadap gugus fungsi yang ditunjukkan pada profil spektra FTIR. Pengamatan morfologi menunjukan butiran-butiran terlihat mengalami aglomerasi akibat gaya antar permukaan yang tinggi. Pola SAED memperlihatkan cincin difraksi yang merepresentasikan bidang-bidang kristal sesuai hasil pola XRD. 


\section{Daftar Pustaka}

1. Chaudhry, Q., Scotter, M., Blackburn, J., Ross, B., Coxall, A., Castle, L., Aitken, R., dan Watkins, R., Applications and implications of nanotechnologies for the food sector, Food Additives and Contaminants, Vol. 25 (2008), p. 241-258.

2. Rani, R., Sharma, S.K., Pirota, K.R., Knobel, M., Thakur, S. dan Singh, M., Electric and Dielectric Study of Zinc Substituted Cobalt Nanoferrites Prepared by Solution Combustion Method, Ceramics International, Vol. 38 (2012), p. 2389-2394.

3. R. Sato Turtelli, M. Atif, N. Mehmood, F. Kubel, K. Biernacka, W. Linert, R. Grossinger, $\mathrm{Cz}$ Kapusta, M. Sikora, Interplay between the cation distribution and production methods in cobalt ferrite, Mater. Chem. Phys., Vol. 132 (2012), p. 832-838.

4. H. Malik, A. Mahmood, K. Mahmood, M.Y. Lodhi, M.F. Warsi, I. Shakir, H. Wahab, M. Asghar, M.A. Khan, Influence of cobalt substitution on the magnetic properties of zinc nanocrystals synthesized via micro-emulsion route, Ceramic International, Vol. 40 (2014), p. 9439-9444.

5. M.A.N. Ismail, M. Hashim, A. Hajalilou, I. Ismail, M.M.M. Zulkimi, N. Abdullah, W.N.A. Rahman, M.S.A.M. Manap, Magnetic properties of mechanically alloyed cobalt-zinc ferrite nanoparticles, J. Supercond. Novel Magn., Vol. 27 (2014), p.1293-1298.

6. Huo, C., Yu, H., Zhang, Q., Li, Y. dan Wang, H., Preparation and magnetic property analysis of monodisperse Co-Zn ferrite nanospheres, J. Alloys Compd., Vol. 491 (2010), p. 431-435.

7. Zak, A.K., Majid, W.H., Abrishami, M.E., dan Yousefi, R., X-Ray Analysis of ZnO Nanoparticles by Williamson-Hall and Size-Strain Plot Methods, Solid State Sciences, Vol. 13 (2011), p. 251-256.

8. Sundararajan, M., Kennedy, L.J., Aruldoss, U., Pasha, S.K., Vijaya, J.J. dan Dunn, S., Microwave combustion synthesis of zinc substituted nanocrystalline spinel cobalt ferrite: Structural and magnetic studies, Materials Science in Semiconductor Processing, Vol. 40 (2015), p. 1-10.

9. Ali, M.B., Maala, K.E., Moussaoui, H.E., Mounkachi, O., Hamedoun, M., Masrour, R., Hlil, E.K. dan Benyoussef, A., Effect of zinc concentration on the structural and magnetic properties of mixed Co-Zinc ferrites nanoparticles synthesized by sol/gel method, Journal of Magnetism and Magnetic Materials, Vol. 398 (2016), p. 20-25.

10. Hassadee, A., Jutarosaga, T. dan Onreabroy, W., Effect of zinc substitution on structural and magnetic properties of cobalt ferrite, Procedia Engineering, Vol. 32 (2012), p. $597-602$.

11. Kumar, A., Yadav, N., Rana, D.S., Kumar, P., Arora, M. dan Pant, R.P., Structural and Magnetic Studies of The Nickel Doped CoFe2O4 Ferrite Nanoparticles Synthesized by The Chemical Co-Precipitation Method, Journal of Magnetism and Magnetic Materials, Vol. 394 (2015), p. 379-384.

12. Panda, R.K., 2015, Sudies on Electric and Magnetic Properties of Cobalt Ferrite and Its Modified System, Thesis, Department of Physics and Astronomy, National Institute of Technology Rourkela, Odisha. 
13. Tatarchuk, T., Bououdina, M., Macyk, W., Shyichuk, O dan Paliychuk, Yaremiy, I., Al-Najar, B. dan Pacia, M., Structural, optical, and magnetic properties of Zn-Doped CoFe2O4 nanoparticles, Nanoscale Res. Lett.,Vol. 12 (2017), p. 141 - 145. 